\title{
Language Contact in Southwestern Europe
}

Kabatek, Johannes ; Pusch, Claus

Posted at the Zurich Open Repository and Archive, University of Zurich ZORA URL: https://doi.org/10.5167/uzh-86162

Book Section

Originally published at:

Kabatek, Johannes; Pusch, Claus (2011). Language Contact in Southwestern Europe. In: van der Auwera, Jan; Kortmann, Bernd. The Languages and Linguistics of Europe. A Comprehensive Guide. Berlin / New York: Mouton de Gruyter, 393-408. 


\section{The World of Linguistics}

\section{Editor}

Hans Henrich Hock

Volume 1

\section{The Languages and Linguistics of Europe}

A Comprehensive Guide

\section{Edited by}

Bernd Kortmann

Johan van der Auwera 


\section{Table of contents}

List of contributors

Introduction

Bernd Kortmann and Johan van der Auwera . . . . . . . . . . . . . . .

ISBN 978-3-11-022025-4

e-ISBN 978-3-11-022026-1

Library of Congress Cataloging-in-Publication Data

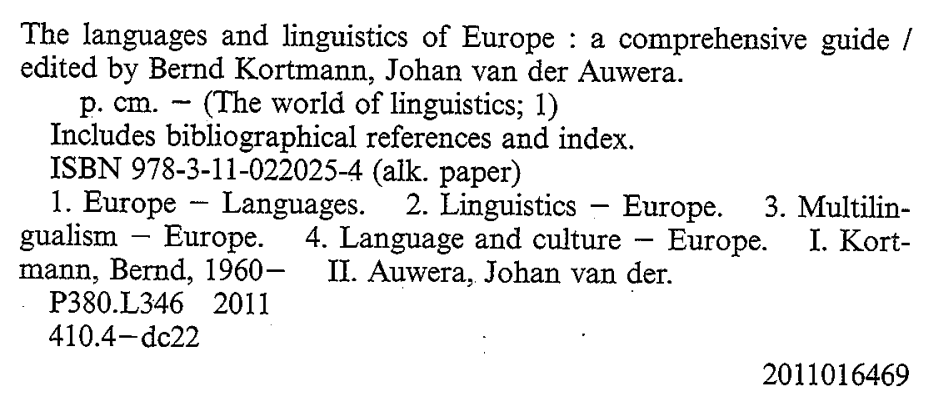

2011016469

Bibliographic information published by the Deutsche Nationalbibliothek

The Deutsche Nationalbibliothek lists this publication in the Deutsche Nationalbibliografie; detailed bibliographic data are available in the Internet at http://dnb.d-nb.de.

2011 Walter de Gruyter GmbH \& Co. KG, Berlin/Boston

Cover image: Thinkstock/iStockphoto

Typesetting: Dörlemann Satz GmbH \& Co. KG, Lemförde

Printing: Hubert \& Co. GmbH \& Co. KG, Göttingen

$\infty$ Printed on acid-free paper

Printed in Germany

www.degruyter.com

\section{Typology of European languages}

1 The Baltic languages

Axel Holvoet . . . . . . . . . . . . . . . . . . 3

2 The Celtic languages

Patricia Ronan . . . . . . . . . . . . . . . . . . . . . . 31

3 The Germanic languages

John Ole Askedal . . . . . . . . . . . . . . . . . . . . . . . .

4 The Romance languages

Johannes Kabatek and Claus D. Pusch . . . . . . . . . . . 69

$5 \quad$ Slavonic languages

Björn Hansen . . . . . . . . . . . . . . . . . . . . . 97

6 The Caucasian languages

Michael Daniel and Yury Lander . . . . . . . . . . . . . . . . . 125

7 The Turkic languages of Europe

Astrid Menz . . . . . . . . . . . . . . . . . . . 159

8 The Uralic languages

Johanna Laakso . . . . . . . . . . . . . . . . . . . . . . . . . 179

9 Albanian

Dalina Kallulli . . . . . . . . . . . . . . . . . . . . . 199 


\section{Ureland, Per Sture}

1977 Some comparative aspects of pronominal cliticization in the Baltic language area. In: Gaberell Drachman (ed.), Akten der 2. Salzburger Frühlingstagung für Linguistik, 301-319. Tübingen: Narr.

\section{Veenker, Wolfgang}

1967 Die Frage des finnougrischen Substrats in der russischen Sprache. Blooming. ton: Indiana University Press.

\section{Language contact in Southwestern Europe}

Claus Pusch and Johannes Kabatek

Introduction

Historical language contact in Southwestern Europe

Pre-Roman languages and Romanization

Language contact from the Arab conquest until the Early Modern period

Modern and contemporary language contact in Southwestern Europe

Language contact between autochthonous languages

Language contact involving dialects

The importance of urban areas and neo-speakers for current language dynamics

The role of education and media

The impact of migration and globalization on language contact

\section{Introduction}

The Southwest of Europe, which for the purpose of this chapter is defined as embracing the Iberian Peninsula, the Balearic Islands and the Southern and Southwestern parts of France between the Gironde and the Rhône estuaries, is a highly interesting area for the study of both historical and contemporary language contact situations. This is mainly due to five reasons: the early and intense Romanization of large parts of the territory; the historical and continuing presence of Basque, the only language isolate in Europe and, at the same time, the only surviving nonIndo-European language in Western Europe, in the core area of this territory (see chapter 10 by Haase); the cultural impact of the Arabic culture during the longlasting presence of Muslims on the Tberian Peninsula; furthermore, in more recent times, the political and demographic changes in Spain, which, due to efficient language planning in favor of the Spanish regional languages, have led to new types of language contact situations; and, finally, the fact that the urban and coastal areas of this territory have attracted migrants from different linguistic and socioeconomic backgrounds, a fact from which still more new types of contact situations ensued.

This chapter will briefly address the issue of the most important and - as far as the present linguistic landscape is concerned - most decisive historical language contact situations from Antiquity to modern times (section 2), but the main focus will be on different facets of the current multilingual constellations found in southwestern Europe and concomitant situations and processes of language contact (section 3). 


\section{Historical language contact}

In the entire area under consideration here, Romance languages are present and spoken by the vast majority of the population as primary languages. These languages developed from the spoken varieties of Latin, which were brought into this territory from the late $3 r$ century BC onwards by soldiers, merchants and colonists through the military, economic and cultural expansion of the Roman Empire. Coastal areas along the Mediterranean Sea were romanized first (from 197 BC on the Iberian coast and from about $120 \mathrm{BC}$ on the Gaulish coast), with inland Romanization advancing at a slower pace, while some mountainous zones in the Pyrenees resisted thorough Romanization until the Middle Ages. For a long time, scholars of Romance linguistic history have emphasized the impact of substrate and superstrate languages for the divergence of the Vulgar Latin spread by the Roman settlers, and for the configuration of today's Romance-speaking Europe. The definition of substrate and superstrate languages implies a period of language contact of variable length that ends in the loss of one of the languages involved, the conquerors' tongue in the case of the superstrate language and the conquered population's tongue in the case of substrate languages. A third term, adstrate, has been coined for a language that is in (long-lasting) contact with (an)other language(s) and exerts influence on it (them). This is a rather infelicitous terminological triad since both superstrate and substrate languages function as adstrate languages for a significant stretch of time, and after territorial retrenchment without complete extinction, a language may be considered a substrate and adstrate language at the same time. Take the case of Basque which is a substrate to Castilian (Spanish) in those areas that it has lost since Romanization, and an adstrate to Castilian nowadays.

\subsection{Pre-Roman languages and Romanization}

Already before the arrival of the Roman conquerors and settlers, Indo-European and non-Indo-European languages co-existed on the Iberian Peninsula. Apart from isolated coastal areas where Phoenician (a Semitic language) and Greek had been brought in through commercial expansion from Greece and Punic Carthage, Celtic languages covered most Western and Central parts of the Peninsula. Iberian and Basque were common in the Northern and Eastern areas, and Tartessian, a non Indo-European language about which very little is known, was spoken in the South. North of the Pyrenees, the Aquitanian language, which is now generally considered to be a precursor of Basque, met with Celtic languages in the North and with ancient Ligurian, probably an Indo-European language which again is scarcely documented, in the East. Two controversial issues have long been discussed by scholars of the language history of Iberia, and both are related to language contact. The first of these is the status of the Celtiberian language, which covered mainly the Ebro basin and adjacent regions. According to recent advances in the interpretation of archaeological testimonies, Celtiberian can be ascribed to the Celtic language group and, more exactly, to the most ancient stratum of Celtic (Echenique Elizondo 2003: 611-612), even if ethnic, cultural and linguistic contact between Celtic and Iberian groups, as suggested by the established denomination of the language, may have been common in the heartland of Iberia, where this language was located. The second controversial issue is the status of the Iberian language and its relation to Basque. From the 19th to the mid 20th century proponents of the so-called 'Vasco-Iberian hypothesis' (which, in nuce, was brought forward as early as in the 16th c. and developed scientifically e.g. by, among others, Wilhelm von Humboldt [1821] and Hugo Schuchardt [1907]) claimed Iberian to be a direct predecessor of Basque. Nowadays, however, a more cautious position prevails according to which Iberian and Basque share certain features, but probably more as a result of prolonged language contact than of common genetic origin. The concept of Sprachbund is sometimes advocated in order to describe the IberianBasque relation. Iberian may have served as a vehicular language well beyond its traditional Eastern-Iberian territory (Echenique Elizondo 2003: 610) and may have transmitted some of its features via Basque to Ibero-Romance, namely to Castilian. Much of this remains speculative due to the fragmented knowledge of the Iberian language system. Basque influence on contemporary Castilian, however, is considered to be beyond doubt. Apart from lexical items, some structural features, such as the sound change of initial etymological /f-/ to /h- / in Castilian, are attributed to Basque influence, just as the reduced inventory of only five vowel phonemes.

Contrary to the not insignificant impact of substrate languages on Romance tongues in Southwestern Europe, Germanic superstrate influence has been very limited, despite the migration (from the early 5th century onwards) and the dominant political position of different Germanic tribes in the area, such as the Vandals, the Suebi and, most prominently, the Visigoths. Two main reasons can be adduced for this fact: first, unlike what happened in Gaul, the Germanic tribes were already strongly romanized when they arrived in the Southwest of the continent; and, second, again unlike later developments in Gaul, the linguistic landscape and distribution of varieties was heavily reshaped between the 8 th and the 15 th centuries due to the conquest of large parts of the Iberian Peninsula by Arab Muslims (711-732) and the subsequent Christian Reconquest (718-1492).

\subsection{Language contact from the Arab conquest until the Early Modern period}

The influence of Arabic (both Classical/written and vernacular/dialectal) on the languages spoken in Southwestern Europe south of the Pyrenees has been studied in detail as far as the lexicon is concerned. On the phonological, morphological or syntactic level, by contrast, only very few, if any, structural features have been 
identified in contemporary Ibero-Romance languages and in Basque which are clearly attributable to language contact with Arabic (or Berber, since many of the conquerors from beyond the Strait of Gibraltar were of Berber origin). During the period of Arab dominance, a situation of multiple language contact and multilingualism emerged which involved Classical Latin, late Vulgar Latin and ProtoRomance varieties, Hebrew (used as a ritual language by the Iberian Jews) and Arabic, leading to a complex constellation of medial and conceptual diglossias. The (Proto-)Romance vernaculars used by autochthonous Iberians, Ibero-Goths and Jews in the Central and Southern parts of the Peninsula continued to evolve under Arab rule; in the 19th century the rather misleading term Mozarabic was coined as a cover term for these varieties. With the advances of the Reconquista, the Romance dialects of the mountainous Northern fringe of the Peninsula, from where the Christian reconquest started, and the subsequent distribution and settlement of speakers of these varieties, 'Mozarabic' was gradually phased out. At the same time the Northern dialects evolved into the Romance languages with their elongated North-South-stretching territories characteristic for the linguistic map of the Iberian Peninsula up to Modern Times, followed by the lateral expansion of Castilian (mainly to the detriment of Asturian-Leonese and Aragonese). Interestingly, among the earliest textual testimonies of Ibero-Romance (as opposed to Latin) are some of the so-called kharjas, final verses of muwashshah poems otherwise written in Arabic or Hebrew (and in Arabic script). They show salient forms of lexical and structural code-mixing, as illustrated by the following transliterated example from the 11th century (García Gómez 1965: 320; Romance elements are italicized):

$$
\begin{array}{ll}
\text { ¡fen, 'indi, habībi! } & \text { come beside me, my friend! } \\
\text { seyas sabitore: } & \text { you should know } \\
\text { tu huyda samaŷa } & \text { your flight is a bad thing } \\
\text { ¡imši, adunu-ni! } & \text { come on, come together with me! }
\end{array}
$$

Both the copulaless predicative construction in the third line and the imperative form based on the Romance verbal root adunar in the last line correspond to the morphosyntax of Arabic. Obviously, literary texts like the kharjas cannot be considered representations of actual oral practice in Muslim-ruled Iberia. But they may well be read as an indication of intense language contact at the time, the precise nature of which unfortunately remains unknown and insufficiently documented.

Due to the Reconquista, the (Proto-)Romance dialects of the Northern Iberian Peninsula extended their territories of use far southwards, while simultaneously forging themselves an identity as autonomous Romance languages different from Latin. Basque, by contrast, did not profit from these expansive moves territorially despite the significant presence of Basque speakers in the Castilian troops. This is probably indicative of an already high degree of bilingualism within the Basque community at this early medieval stage. Another important facet of post-Reconquista migration and linguistic contact is the increase of pilgrimages to the tomb of St James (Santiago) in Galicia in the Iberian Northwest, which developed from the 9th century and attracted pilgrims from across Europe from the 11th century onwards. Along the main routes on the Northern peninsula, many Gallo-Romancespeaking clergymen, traders and craftsmen settled and constituted the - frequently economically privileged - social group of Francos. Among these, Occitan (langue $d^{\prime} o c$ ) and French (langue d'oïl) varieties were current both as mediums of oral and written communication (Martínez González 2006). Furthermore, Occitan as a leading high variety for literary (especially lyrical) use during the 12 th and 13 th centuries had a significant impact on the Romance varieties on the Eastern edge of the Peninsula (now forming the Catalan diasystem). Significantly, the first known 'grammar' of a Romance language, the Razós de trobar written by the Catalan poet Ramon Vidal de Besalú in the early 13th century, is dedicated to a description of (literary trobadoresque) Occitan, and this language remained influential in the Catalan-speaking zones until at least the 15 th century.

\section{Modern and contemporary language contact in Southwestern Europe}

Today, apart from the small territories of the Principality of Andorra and the British colony of Gibraltar (see section 3.2), the Southwest of Europe is divided between the three nation-states of France, Spain and Portugal. Linguistically speaking, these three countries have in common that their dominant national languages are considered as world languages on the basis of their geographical distribution outside of Europe and their high numbers of L1 and L2 speakers. This gives considerable prestige to these languages, a fact that has an obvious influence on the language contact situations and linguistic attitudes in these countries. At the same time, all three states have been important colonial powers (in the case of France and Portugal until the mid/late 20th century), a fact that has an impact on current immigration patterns in these countries.

On the other hand, France, Spain and Portugal differ significantly as far as linguistic plurality and language policy are concerned: France has traditionally been considered a politically and linguistically centralized state with low esteem for dialects or 'regional' languages and little interest in the promotion of linguistic diversity, emphasizing the unifying role of but one linguistic variety, namely Standard (or near-Standard) French. This attitude was given legal expression in the 1992 addition to the French constitution stating that the language of the French Republic is French, a clause preventing the ratification of the European Charter for Regional and Minority Languages by France (cf. Ager 2008). Along with its proclaimed national monolingualism, the French government has pursued a rather ambiguous and contradictory language policy during the last decades as, to a certain extent, 
linguistic plurality has been acknowledged, after all, through measures in the realm of education and cultural affairs. Portugal, too, has claimed national monolingualism for a long time, but contrary to France, where this linguistic homogeneity has always been ideologically motivated and 'constructed', it corresponds largely to the linguistic reality of Portugal. Dialectal divergences are moderate in European Portuguese - as in most Ibero-Romance varieties outside the northern fringe of the Peninsula - and Mirandese, an Astur-Leonese dialect spoken by some 7,000 people in the Northeast of the country, is the only territorialized non-Portuguese language in Portugal and legally recognized as such since 1998. Post-Franquist Spain, on the other hand, explicitly recognizes its linguistic diversity in the 1978 constitution which, in art. 3.2, declares "the other languages of Spain" (i.e. Basque, Catalan, and Galician) as co-official in the corresponding autonomous regions alongside with Castilian/Spanish, the official and obligatory language of the whole state. However, linguistic plurality is far from being an uncontroversial issue in contemporary Spain. According to the Spanish constitution, official and social multilingualism is restricted to territorially (and, to a certain extent, ethnically) circumscribed areas. In contrast to federally organized states such as Belgium or Switzerland, language contact situations between autochthonous languages and the state language are therefore limited to these (officially or non-officially) bilingual regions. Vertical language contact is found in the entire country between the autochthonous language(s) and non-autochthonous dialects/languages of migrants, but again these processes are particularly salient and problematic (and best studied) in the bilingual regions. In Southwestern France and in Portugal, the situation is less intricate; vertical and horizontal language contact phenomena (the latter being almost nonexistent in Portugal) evolve independently from each other.

\subsection{Language contact between autochthonous languages}

Contrary to what happened in the central and southern parts of the peninsula due to the effects of Christian reconquest and resettlement, the autochthonous languages in Southwestern France and Northern Spain have evolved continuously and therefore developed as regular dialectally diversified continua. Dialectalization namely of the Asturian varieties of Astur-Leonese, Basque, Aragonese and Occitan was fostered by the absence of a standardized written form of these languages. Generally accepted standard varieties currently exist for Catalan (on the basis of Pompeu Fabra's early 20th century codification) and Basque (in the form of Euskara batua, introduced in the 1960s). The conflicts on the written forms of Galician and Occitan - at least in the areas focused on here - were settled in favor of the codifications of the Royal Galician Academy and of Louis Alibert, respectively. However, the weak institutional support for Standard Occitan and for a coherent language policy has allowed the situation to deteriorate towards advanced language decay in many Occitan-speaking areas of Southwestern France. Traditional Occitan dialects have been replaced by Occitan varieties heavily influenced by Standard or near Standard French (these are known as francitan) or by tertiary dialects of French characterized by Occitan substratal features (known as Regional French). Contact phenomena in French-influenced hybrid Occitan varieties are found in the lexicon, of course, but also on the phonetic level (i.e. substitution of apical [r] by uvular $[R]$ ) as well as on the morphological and morphosyntactic levels (e.g. the decay of simple past forms and the rise of periphrastic present perfect forms analogous to the French passé composé). Peculiar features of the Gascony Occitan varieties are generally well conserved since they constitute emblematic characteristics of these varieties (e.g. the preverbal evidential-like 'enunciative' particles or initial $\mathrm{h}-/$, which originates from Latin /F-/). A special process of dialect leveling is taking place in the Gascony Occitan variety of the Aran valley in Northwestern Catalonia. This variety is exposed to influence from Catalan, Aragonese and, in recent periods, Spanish. The joined effects of officialization of the dialect on the basis of a slightly differential codification, increased mobility and a different perception of the political frontier with France seem to strengthen linguistic individualization of Aranese Occitan despite its declared affiliation with Occitan in France. Another situation of convergence has arisen in the French part of the Basque Country: traditionally, language contact took place between the Iparralde dialects of Basque and the Gascon dialects of Occitan. In modern times, borrowed features from Occitan have facilitated transfers from the new prestige language French (cf. Haase 1992), and the horizontal dynamics of language contact between geographically adjacent languages have been converted into vertical language contact between traditional regional tongues and the dominant national language. However, such a view inevitably implies much simplification, since today French in Southwestern France is also a deeply rooted language, which is neither any longer considered as non-autochthonous nor as 'imposed' by the vast majority of speakers, not even in rural areas, where French constitutes the primary means of communication.

The situation is different in the bilingual regions south of the Pyrenees and, more specifically, in the regions known as 'historical autonomous communities', i.e. the Basque Country (Euskadi), Galicia and Catalonia. Their rural areas are characterized by a generally high degree of dominance of the regional languages in informal conversation and partly also in formal contexts, with the national language Spanish frequently being perceived as 'imported' and alienating, despite a generally sufficient mastery of it. Zones of intense language contact are therefore mainly found in the border areas of the language territories, on the one hand, and in the urban and semi-urban areas, on the other hand, where regional language and national language clash most saliently. A dialectologically emblematic example of the former is the contact zone between Catalan, traditional Aragonese and the tertiary dialects of Aragonese Spanish (which tend to replace the primary Aragonese dialects in the modern age) in Western Catalonia and Eastern Aragón. For Catalan 
speakers in Aragón, the position at this linguistic crossroad leads to conflicts of identity (cf. Fort-Cañellas 2007). These, in turn, contribute to phenomena of linguistic hybridization comparable to francitan, whereas such hybrid varieties do not exist in other parts of the Catalan-speaking area. A situation comparable to that of Eastern Aragón is found at the border zone between Galician and Asturian dialects in the western Principality of Asturias. In the heartlands of the historical autonomous communities, however, considerable efforts have been made in both status and corpus planning. As a result, the regional languages have been consolidated and the former patterns of functional and medial diglossia have been modified or to a certain extent, even reversed, especially in the case of Catalan in Catalonia. In all officially bilingual autonomous regions there is an increasing number of people who declare to master the basic skills of understanding, speaking, reading and writing the regional language involved (i.e. Catalan in Catalonia, the Valencian Region and the Balearic Islands; Basque in Euskadi and Northern Navarra/Nafarroa, and Galician in Galicia). Recent sociolinguistic research has shown, though, that such figures tell us only part of the truth: while competence in using the regional languages in written form has indeed gone up remarkably, actual (oral) use of these languages does not follow at the same pace or even stagnates (cf. Casesnoves Ferrer, Sankoff and Turrell 2006 and Vila i Moreno 2008 for data on Catalan; Aizpurua Telleria and Aizpurua Espin 2005 on Basque, Monteagudo and Bouzada Fernández 2003, on Galician). Generally, and again most prominently in urban areas, the numbers of speakers who declare themselves to be bilingual have increased. The interpretation of proclaimed bilingualism differs according to the region: whereas in the Basque-speaking area it is considered as a positive development by language planners and activists, in Catalan-speaking regions it is often seen more critically as a symptom of declining loyalty towards the regional language.

The bilingual historical autonomous communities in Spain present an array of classical contact phenomena in the vernaculars of these areas. Apart from the notoriously frequent borrowings on the lexical level (e.g. with regard to syntactically loosely integrated elements such as discourse markers), transfers and calques exist on all other levels of linguistic structure, too. Hitherto, such contact phenomena have mainly been studied from the perspective of the regional language, but the perspective taken on these phenomena has widened in recent years, probably as a side-effect of the sociolinguistic consolidation of these languages. So now there is an increased interest in studying contact phenomena, language dynamics and underlying attitudes from the perspective of the national language Spanish, too (cf. the thematic issues 184 [2007] and 193/194 [2008] of the International Journal of the Sociology of Language, or Sinner and Wesch 2008 with a focus on the Catalan-speaking regions). In accordance with the sociolinguistic finding that the relations of diglossic super- and subordination can no longer be described as easily as they were in pre-democratic Spain, contact-induced features also seem to evolve more strongly in both directions. For instance, the loss of the distinction between voiced and unvoiced /s/ - a phonemic distinction in Catalan but not in Castilian has long been described in terms of Spanish influence on Catalan. But the reverse process of introducing voiced $/ \mathrm{s} /$ - albeit, for the time being, as a mere allophonic variant - is now also attested and described as a Catalan influence on Catalonian Spanish. Such insights lead to a new perception of the contact varieties of Spanish with autochthonous languages, in that Spanish spoken with a Catalan, Basque or Galician 'accent' is no longer denigrated as deviant or "bad" Spanish, but as full-fledged tertiary Spanish dialects or instances of Regional Spanish.

\subsection{Language contact involving dialects}

The term dialect is notoriously difficult to apply, especially in opposition to language, and this holds for France and Spain in a particularly acute way. Just take Asturian and Aragonese (see e.g. Kabatek 2006), for which language status is claimed by local activists and some linguistic scholars, while other scholars advocate dialect status for them (in the sense of: dialects of Spanish). Among the uncontroversial European Spanish dialectal varieties, the case of Andalusian as the most distinctive dialect has attracted special attention (cf. Narbona 2009). A very peculiar contact situation, bringing together Andalusian and English, is found in the British colony of Gibraltar, which had been occupied by British troops in 1704 and integrated into the United Kingdom in 1713. Despite British presence (mainly military) for more than 300 years, Andalusian Spanish has remained the dominant oral language on the "Rock", despite the existence of a structurally still Spanishdominant contact variety called Yanito (or Llanito; cf. Levey 2008). This variety is characterized mainly by lexical loans from English but also from Caló (the Spanish Gipsy language), Italian and other languages of the Western Mediterranean. Thus, English terms for realia unknown in or uncommon for Spanish culture up to the mid-20th century have been adapted phonologically, yielding loanwords such as chinga (<chewing gum) or arishu (<Irish stew) (Levey 2008: 5). Language use and language attitudes in Gibraltar are as controversial in research as is the whole Gibraltar issue in politics. Many Spanish scholars emphasize the linguistic loyalty of Gibraltarians towards their Romance language due to consciousness of their Hispanic roots (Martínez González 2006: 1875). British and other non-Spanish authors, on the other hand, claim that the use of Spanish is dwindling in favor of higher competence and esteem for and use of (British) English as an expression of non-Spanish identity and pro-British feelings. The latter have been strengthened significantly since the vociferous claims for a return of Gibraltar to Spain by Franco's government in the 1960's and the Spanish blockade of the terrestrial access to the "Rock" between 1969 and 1982. 
3.3. The importance of urban areas and neo-speakers

for current language dynamics

It is common sociolinguistic knowledge that urban areas constitute poles of attraction and, at the same time, centers from which linguistic innovations and 'fashions' irradiate, and that cities and conurbations serve as ethnic and cultural foci and melting-pots. Traditional language varieties are assumed to be much better preserved in the linguistically conservative rural areas, whereas the urban centers are generally associated with dialect leveling and loss of traditional ways of speaking. However, language preservation movements and language standardization initiatives often originate in urban societies among intellectual elites frequently linked to cultural and academic institutions.

A recurrent figure in urban linguistic activists' movements is the neo-speaker. This is a person whose first language has not been the regional variety but the dominant national tongue and who has grown up, and frequently continues to live, in a social surrounding where the dominant language is the current means of expression. At a certain point in her or his life, this person has decided, however, to use the regional variety or language regularly and as consistently as possible for daily communicative purposes. Neo-speakers are particularly numerous in the Basque-speaking areas, where they are known as euskaldun berriak and tend to outnumber native (L1) speakers of the language (Aizpurua Telleria and Aizpurua Espin 2005: 51-52), but they are also common in Galicia, in Occitan-speaking France, and other areas, too. These neo-speakers, due to their urban background and educational qualifications, are frequently active in professional areas that contribute to language diffusion, such as the media or education (cf. Kabatek 1996 for Galician cases). When expressing themselves in their language of deliberate choice, they tend to apply the ordinary strategies of L1-to-L2 transfer. Yet at the same time they tend to exhibit strong - excessively strong, as some would claim attitudes of linguistic purism, which manifests itself in the over-representation of emblematic and often highly conservative features in their speech and in the avoidance of linguistic elements that could be interpreted as a loan or an interference from the dominant language. L1 speakers of the regional variety or language, especially elderly people, are usually rather critical concerning the neo-speakers' linguistic output. At the same time, as the situation of Basque suggests, these speakers and their innovative and at the same time conservative way of speaking will most certainly be decisive for the future of many regional languages, not only in the geographic area presented in this contribution.

\subsection{The role of education and media}

The educational sector is known to be a key area of intervention in policies aiming at reversing language shift, and it has also become a primary arena for language contact. Together with the media, schools are the platforms for diffusion of stan- dard varieties and, as such, contribute significantly to linguistic convergence and integration. The ways in which linguistic diversity is handled in the school systems differ significantly in the area under scrutiny here. In France, the almost exclusive language of teaching is Standard French but regional languages can be taught on a voluntary basis since the Deixonne law of 1951. In some regions, including Southwestern France, bilingual programs are now available in public secondary schools, as well as (theoretically) monolingual teaching in the regional languages in private primary schools (so-called calandretas in the Occitan-, iskastolak in the Basqueand bressola schools in the French Catalan-speaking areas). In Spain, Catalan is the dominant school language in Catalonia (cf. Muñoz 2005; Vila i Moreno 2008) and the Balearic Islands, where immersion methods are applied, while in the Valencian Country predominantly Spanish- or Catalan-taught programs exist side by side, with the teaching of Valencian Catalan remaining compulsory though. In Euskadi a more diversified system with different degrees of Basque presence exists, the main tendency nowadays being the preference for the dominantly Basque option (cf. Cenoz 2009). In Galicia, Galician is dominant even though Spanish is strongly present. As mentioned before, these educational policies have improved the basic language skills in the regional languages, generally without reducing the students' competence in the national language. However, this heavy presence of the regional language(s) as object and medium of teaching and as regular medium of communicative exchange within the school has not led to an equal presence of these languages in the schoolyard and outside, neither in areas with strong social support for this educational policy (like Catalonia or Euskadi) nor in zones with weak social backing (such as the Valencian Country or Southwestern France). Many children for whom the regional language is not the L1 and/or the ordinary means of expression in daily life (and apart from Catalonia and Galicia, these children tend to constitute the majority in the classrooms) perceive this language as "the language of school", as opposed to the language in usage for "life outside school", which for many of them is the national language. This does not imply a negative attitude towards the regional language; on the contrary, in the eyes of the schoolchildren this language is generally the more prestigious one. Recent research in Catalonia (Woolard 2009) has shown that secondary school students in the Barcelona area consider Catalan the more cultivated and 'elegant' language, whereas Castilian is qualified as 'coarse' and vulgar, and this independently from the L1 background of the students. This means that students know register variation - including casual speech and hybrid, contact-influenced forms of speaking for Spanish only, but that no such diastratic or diaphasic variation is perceived for Catalan. This partly explains the reluctance to use Catalan in ordinary communicative contexts. Furthermore, the normative impact of the standard variety, which is dominant in the educational system, may also have a surprising effect in that children with an L1 background in the regional language experience increasing linguistic insecurity with greater knowledge of the norm, while students whose L1 
is the national language do not feel insecure in the same way when expressing themselves in the regional idiom (cf. Baldaquí 2009).

Another important area for language planning and diffusion of standard varieties is the media, most prominently the electronic media, which is considered to contribute strongly to processes of linguistic convergence. Regional languages have a merely anecdotal presence in the media in France, while their role in the Spanish media landscape is more prominent. Broadcasting companies in the autonomous communities in Spain are generally extremely aware of the issue of linguistic diversity and language contact phenomena, and try to keep variants apart as neatly as possible with sometimes remarkable expenditures on monitoring devices (cf the contributions in Kabatek and Pusch 2009). This applies both to the contrasts between regional and national language and between dialectal varieties of the regional tongues.

\subsection{The impact of migration and globalization on language contact}

Internal (national) migration has had important effects on the linguistic composition of the bilingual regions on the periphery of the Spanish state during many decades of the 20th century, generally strengthening the presence of the national language. This holds particularly for the industrial centers in Catalonia, Euskadi and, to a somewhat lower degree, Asturias. Galicia, as well as many other regions in Spain and Portugal, and Southwestern France have been zones of (internal or external) emigration rather than immigration. This has changed drastically with the development of mass tourism from the 1960s onwards and with the so-called 'new', globalization-driven migration initiated at the end of last century. These waves of migrants are obviously very diverse concerning origin, socio-economic background, and motivation, but they converge in creating even more complex scenarios of functional language distribution and language contact.

The new migrant minorities in Spain and Portugal consist, roughly speaking, of groups from Latin America, Western and Northern (Maghrebian) Africa, and Eastern European and Balkan countries. Within these groups, migrants from Ecuador and Colombia, Morocco, and Romania are demographically dominant in Spain, whereas in Portugal the most prominent countries of origin are Cape Verde and other former African colonies, Ukraine and - although with some distance - Brazil. In France, by far the most immigrants are of Maghrebian/African origin; Latin American immigration is insignificant and Asian immigration is more importan than on the Iberian Peninsula. The preferred destination of immigrants to Portugal is the Lisbon capital region, whereas in Spain immigrants cluster in Madrid and along the Mediterranean coast, with a particularly high concentration in the Catalan-speaking regions. Many, if not most Africans migrating to France and Portugal, as well as Latin Americans coming to Portugal and Spain, know and master the national language of their host country either on $\mathrm{L} 1$ or on comparatively high com- petence levels, a fact that despite undeniable dialectal divergences facilitates communication and integration. There is a risk that matters will evolve less smoothly in the bilingual regions, especially when immigrants ignore the multilingual reality of these areas upon their arrival. This is why Catalonia, for example, tries to give information on this issue in advance through information campaigns in the most important countries of origin of the immigrants, an effort that is frequently in vain due to the proportion of clandestine immigration. The picture of language attitudes and linguistic behavior of Spanish-speaking Latin Americans who settle in the bilingual autonomous communities in Spain remains unclear for the time being, and results from research on this issue are sometimes contradictory. However, as far as Catalonia is concerned, it seems that the stereotype of the Spanish-speaking immigrant who is reluctant or totally unwilling to adapt to and communicate in Catalan is not (or no longer) valid. Latin Americans, as well as the other immigrants considered here, come to Spain in search for better economic conditions. Thus they all realize that knowledge of the regional language enhances the opportunities to achieve this goal, which may in turn justify the additional effort of getting acquainted with it. At least among Latin American students and youngsters, attitudes towards institutional and social bilingualism and towards Catalan seem to be positive (cf. Huguet and Janes 2008). For immigrants with other linguistic backgrounds, especially those speaking primarily African languages and French, learning Spanish or Catalan represents an equally huge extra effort, so that these persons are less biased concerning the initial language of integration into the host society. Depending on age, place of residence, and the professional situation, these persons start to integrate via Catalan, Spanish or both at the same time (cf. Juarros-Daussà and Lanz 2009). Not surprisingly, many school teachers in the bilingual regions have a particular empathy towards language diversity and welcome the presence of additional languages in the classroom as an enrichment (Palou and Fons 2009). If such attitudes, in turn, are communicated to immigrant children who (also) speak rather 'exotic' (regional, tribal or indigenous) languages from their country of origin, a feeling of pride can arise which leads to beneficial effects on their integration into the bilingual host society and a full acceptance of the regional language as a means of normal daily expression. Empirical findings show, however, that since these students adapt gradually to the linguistic behavior of their autochthonous classmates, an increase in the use of Spanish takes place by the time they reach adolescence.

The situation is different for immigrants from Central and Northern Europe, who migrate to the southwest of the continent either as (mostly young) professionals or as retirees. These waves of migrants are particularly strong in the case of Mediterranean Spain (where residents of British, German and French origin predominate) and Southern Portugal (with Britons, Germans, and Dutch residents), while (as yet) being of marginal importance in Southwestern France. Generally speaking, the ethnic and socio-economic background of these migrants gives them 
more freedom to decide if, and to what extent, they wish to integrate linguistically into the receiving society. These migrant groups frequently organize in relatively hermetic, ghetto-like communities with their own service and communication networks, and the above-mentioned professionals usually find their customers among (mainly the elderly of) their compatriots. For professional activity in a foreign country, a basic knowledge of (one of) this country's language(s) would seem unavoidable, but the increasing availability of English as a lingua franca in communicative exchanges with the autochthonous population must be also taken into account. As far as 'vacational' and retirees' immigration is concerned, these migrants are generally perceived as indifferent towards language questions and linguistic integration, and as hostile to any political measures implying the obligatory use of regional languages. But actually, little research has been carried out in this field so far and the reality might well turn out to be quite different than this general perception suggests (for some first case studies in Spain, cf. Turrell 2001).

See also the following chapters in this volume: 10 by Haase, 24 by Troester-Mutz, 25 by Extra, 29 by Darquennes, 38 by Ramat and 44 by Wright.

\section{References}

Ager, Dennis

2008 French and France: Language and state. In: Guus Extra and Durk Gorter (eds.) Multilingual Europe: Facts and Policies, 87-110. Berlin/New York: Mouton de Gruyter.

Aizpurua Telleria, Xabier and Jon Aizpurua Espin

2005 The sociolinguistic situation in the Basque Country according to the 2001 Sociolinguistic Survey. International Journal for the Sociology of Language 174 $39-54$.

Baldaquí Escandell, Josep M.

2009 Inseguretat lingüística o consciència normativa? Inseguretat i ús de la llengua entre els joves valencians [Linguistic insecurity or normative consciousness? Insecurity and language use among young Valencians]. Zeitschrift für Katalanistik 22: 71-94.

Casesnoves Ferrer, Raquel, David Sankoff and M. Teresa Turrell

2006 Linguistic shift and community language: The effect of demographic factors in the Valencian Region, Balearic Islands and Catalonia. In: Clare Mar-Molinero and Miranda Stewart (eds.), Globalization and Language in the SpanishSpeaking World. Macro and Micro Processes, 197-219. Basingstoke: Palgrave Macmillan.

Cenoz, Jasone

2009 Achievements and challenges in bilingual and multilingual education in the Basque Country. AlLA Review 21: 13-30.
Echenique Elizondo, María Teresa

2003 Substrato, adstrato y superestrato y sus efectos en las lenguas románicas: Iberorromania. In: Gerhard Ernst, Martin-Dietrich Gleßgen, Christian Schmit and Wolfgang Schweickard (eds.), Romanische Sprachgeschichte. Histoire linguistique de la Romania. 1. Teilband/Tome 1, 607-621. Berlin/New York: Mouton de Gruyter

Fort-Cañellas, María Rosa

2007 Sociolinguistics on the Aragon-Catalonia border. International Journal for the Sociology of Language 184: 109-119.

García Gómez, Emilio

1965 Las jarchas romances de la serie árabe en su marco. Madrid: Sociedad de Estudios y Publicaciones.

Haase, Martin

1992 Sprachkontakt und Sprachwandel im Baskenland. Einflüsse des Gaskognischen und Französischen auf das Baskische. Hamburg: Buske.

Huguet, Angel and Judit Janes

2008 Mother tongue as a determining variable in language attitudes. The case of immigrant Latin American students in Spain. Language and Intercultural Communication 8: 246-260.

Juarroz-Daussà, Eva and Tilman Lanz

2009 Re-thinking balanced bilingualism. The impact of globalization in Catalonia Language Problems \& Language Planning 33: 1-21.

Kabatek, Johannes

1996 Die Sprecher als Linguisten. Interferenz- und Sprachwandelphänomene dargestellt am Galicischen der Gegenwart. Tübingen: Niemeyer.

Kabatek, Johannes

2006 Requisitos para ser lengua: el caso del asturiano y de otras modalidades lingüísticas de España. In: Mónica Castillo Lluch and Johannes Kabatek (eds.), Las lenguas de España. Politica lingüistica, sociología del lenguaje e ideologia desde la Transición hasta la actualidad, 141-158. Frankfurt am Main/ Madrid: Vervuert/Iberoamericana,

Kabatek, Johannes and Claus D. Pusch (eds.)

2009 Variació, poliglòssia i estàndard. Processos de convergència i divergència lingüistiques en català, occità $i$ basc [Variation, Polyglossia and Standard. Processes of Linguistic Convergence and Divergence in Catalan, Occitan, and Basque]. Aachen: Shaker.

Levey, David

2008 Language Change and Variation in Gibraltar. Amsterdam/Philadelphia: Benjamins.

Martínez González, Antonio

2006 Hablantes alóglotos en la Península Ibérica. In: Gerhard Ernst, Martin-Dietrich Gleßgen, Christian Schmitt and Wolfgang Schweickard (eds.), Romanische Sprachgeschichte. Histoire linguistique de la Romania, 2. Teilband/Tome 2, 1870-1878. Berlin/New York: Mouton de Gruyter.

Monteagudo, Henrique and Xan M. Bouzada Fernández (eds.)

2003 O proceso de normalización do idioma galego. Vol. III: Elaboración e difusión da lingua [The Normalization Process of the Galician Language. Vol. III: Elab- 
oration and Diffusion of the Language]. Santiago de Compostela: Consello da Cultura Galega.

Muñoz, Carmen

2005 Trilingualism in the Catalan educational system. International Journal for the Sociology of Language 171: 75-93.

Narbona, Antonio

2009 La identidad linguiiśstica de Andalucía. Sevilla: Centro de Estudios Andaluces.

Palou, Juli and Montserrat Fons

2009 Actituds dels docents davant les noves situacions escolars multiculturals i multilingües: qüestions recurrents [Attitudes of teachers concerning the new multicultural and multilingual situations in school: recurrent topics]. Zeitschrift für Katalanistik 22: 151-169.

\section{Schmid, Beatrice}

2006 Contactos lingüísticos interrománicos en la Península Ibérica. In: Gerhard Ernst, Martin-Dietrich Gleßgen, Christian Schmitt and Wolfgang Schweickard (eds.), Romanische Sprachgeschichte. Histoire linguistique de la Romania, 2. Teilband/Tome 2, 1785-1800. Berlin/New York: Mouton de Gruyter.

Sinner, Carsten and Andreas Wesch (eds.)

2008 El castellano en las tierras de habla catalana. Madrid/Frankfurt am Main: Iberoamericana/Vervuert.

Turrell, M. Teresa (ed.)

2001 Multilingualism in Spain. Sociolinguistic and Psycholinguistic Aspects of Linguistic Minority Groups. Clevedon: Multilingual Matters.

Vila i Moreno, F. Xavier

2008 Catalan in Spain. In: Guus Extra and Durk Gorter (eds.), Multilingual Europe: Facts and Policies, 157-183. Berlin/New York: Mouton de Gruyter.

\section{Woolard, Kathryn A.}

2009 Linguistic consciousness among adolescents in Catalonia: A case study from the Barcelona urban area in longitudinal perspective. Zeitschrift für Katala nistik 22: 125-149.

\section{Language contact in South-Eastern Europe}

\section{Peter M. Hill}

Introduction

The history of language contact in SEE

The Roman conquest

The arrival of the Slavs

The arrival of the Proto-Bulgarians

The arrival of the Magyars

Byzantine and Modern-Greek influence on Bulgarian and Serbian

Latin and German influence

Trade

The Ottoman invasion

The rôle of the towns

Transhumance and pečalba

The Establishment of the Nation-States

Contemporary developments

Minorities in the nation-states

Anglomania

Other influences

The resurgence of the Turkisms

Conclusion

\section{Introduction}

Our knowledge of language contact in South-Eastern Europe (SEE) in the premodern era is fragmentary and to some extent based on speculation, but it was undoubtedly widespread and intense and led to the rise of the so-called "Balkan Linguistic League" (Balkansprachbund). In Macedonia, for instance, in the prenational period adult men typically spoke a number of different languages or dialects. In SEE as elsewhere in the world, dialects of the same language can influence one another: peasants from different villages meet at the market, on the way to the market and at fairs and at festivals and this sometimes leads to the creation of interdialects. In SEE under Ottoman rule, Turkish was the language of the towns, especially in commerce and administration, as well as that of some villages. Turkish retained its prestige among urban dwellers well into the 20 th century and even up to today in Macedonia and Kosovo (Friedman 2002). In the Bulgarian-speaking territories there was contact between Bulgarian as the indigenous language, Greek as the language of trade and culture and the language of instruction in secular schools (Goebl et al. 1997: 1489; Hinrichs 1999: 812) and Turkish as the language of the Ot- 